GA を用いた多段階物流センター最適立地選定に関する研究*

\title{
Research for Optimal Location of Multiechelon Distribution Center Based on Genetic Algorithm
}

\author{
相浦 宣徳**佐藤 馨一***唐澤 豊****角田 直登 ${ }^{* * * * *}$
}

Nobunori AIURA, Keiichi SATOH, Yutaka KARASAWA and Naoto TSUNODA

\section{1. はじめに}

昨今、都市内及び都市間物流の交錯により、CO2、 $\mathrm{NOx}$ 等の排出に代表される環境問題や交通渋滞が引き起こされ ている。これに対し、物流システム改善の一環として物流イ ンフラ整備における、規制緩和、誘導等のソフト面からの施 策及びハード面の施策が検討されている。

ソフト面での施策は導入期間が比較的短期間であること、 財政上の負担が少ないことから有用視されているが、同時に 物流以外一の影響が桬念されている。一方、ハード面の施策 においては施行後の効果は多分に期待できるものの、インフ ラ整備に長時間を要し、費用的にも負担が大きい等の問題が ある。

このため、既設設備の有効利用を前提とした物流システム の改善が模索されており、具体的には、物流拠点の統廃合、 共同輸・配送による効率化等々に見られるような費用面、時 間面において比較的負担が少ない改善が進められている。

このような社会的背景と共に、近年の企業戦略として、 物流拠点の最適配置による物流費用の削减が大きくとりあ げられている。事実、生産拠点からの全国レベルへの輸配 送を考える場合、中間チャネルとなる物流拠点の在り方が 交通渋滞PCO2、NOx排出に直接関係する運行距離、積載効 率あるいは車両回転率に及ぼす影響は大きく、抜本的な解 決手法が求められている。しかしながら、これまで多段階 工場立地問題の解法として MMFLA (Multiechelon Multiactivity Facility Location Allocation)モデル等々が提昌、研 究されてきたが、生産拠点の合理化や、市場(エリア)に対 する物流拠点の立地に関してはほとんど研究されてこなか った。

\section{本研究はハード面からの社会的物流インフラ配置問題解}

\footnotetext{
*キーワード 産業立地、最適化技法

*学生員 修(工) 北海道大学大学院工学研究科都市環境工学専攻

(札幌市北区北 13 条西 8丁目、Tel 090-4729-2228、Fax 011-706-2296)

フェロー 工博 北海道大学大学院工学研究科都市環境工学尃攻

（札幌市北区北 13 条西 8丁目、Tel 011-706-6209、Fax 011-706-2296)

正員 工博 神奈川大学大学院工学研究科経営工学専攻

（横浜市神奈川区六角橋三丁目 27 番 1 号、Tel 045-481-5661、Fax 045-4136565)
}

正員 修(工) 日本電気（株）

（横浜市港南区大久保 3-3-25NEC 上大岡 4006）
決の第1歩として、ある企業において現実に提示されている 物流センター立地問題の解決、並びに多段階物流センター 最適立地問題の解法の確立を目的とした。すなわち、輸送 コストをベースとした多段階物流センター立地選定モデル の開発を行い、さらに製品在庫の持ち方、各物流センター 拠点候補地における人件費、地代家賃等から発送管理費、 在庫維持費等のセンター運営費を考虑した多段階立地選定 モデルへの発展を図った。

\section{2. 問题設定}

本研究において取り上げた多段階物流センターの階層図 を図 1 に示した。異なる製品を生産する工場から、1 次輸送 を経て各物 流センター に総ての製 品が輸送さ れる。物流 センターで は一定期間 分の在庫量 を確保しつ つ、担当す るエリアか らの受注に より市場の 顧客へ配送 する(2 次輸 送)。

この企業で は物流セン ターの合理 化を進めて おり、(1)物 1)生産工場: 全国6 捄

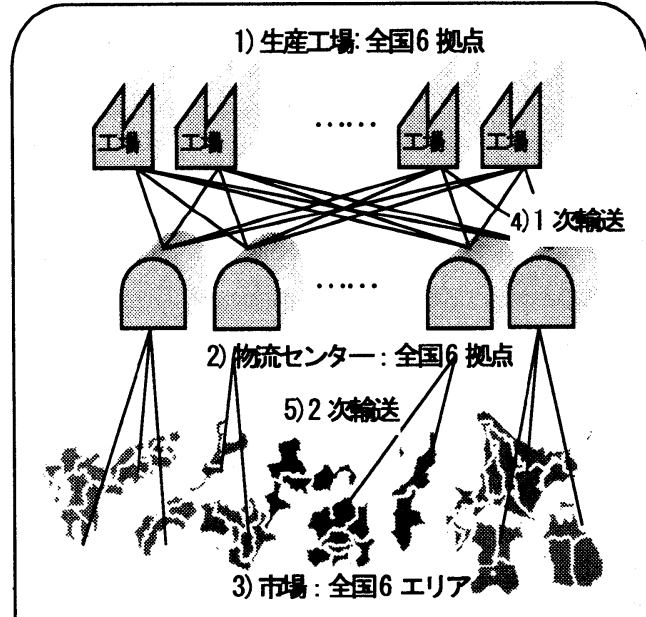

1)生産工場 : 各々異なる製品を生産

2)物流センター : 総ての製品を扱い、担当エリ ア内の市場 配送寸る

3)市場 : 県単位で 6 エリアに分割

4) 1 次輸送: 宅配便最大単位 (25kg 以下)て輸送 5) 2 次輪送 : 顧客先注文単位C宅西己便輸送

図1:多段階物流センターの階图

流センターの統廃合、(2)製品在庫の持ち方、(3)エリアの再配 分等々の検討が行われている。 


\section{3. 物流センター立地モデルの楎築}

物流センター立地モデルの全体構成を図 2 に示す。本モ デルは物流セ

ンター立地と 在庫維持費等 の物流センタ 一運営費に関 する立地総コ ストの最小化 を図るもので ある。

最適配置問 題は 17 世紀初 頭の”フェルマ 一問題”を先駆 けとし、19 世 紀後半のラウ

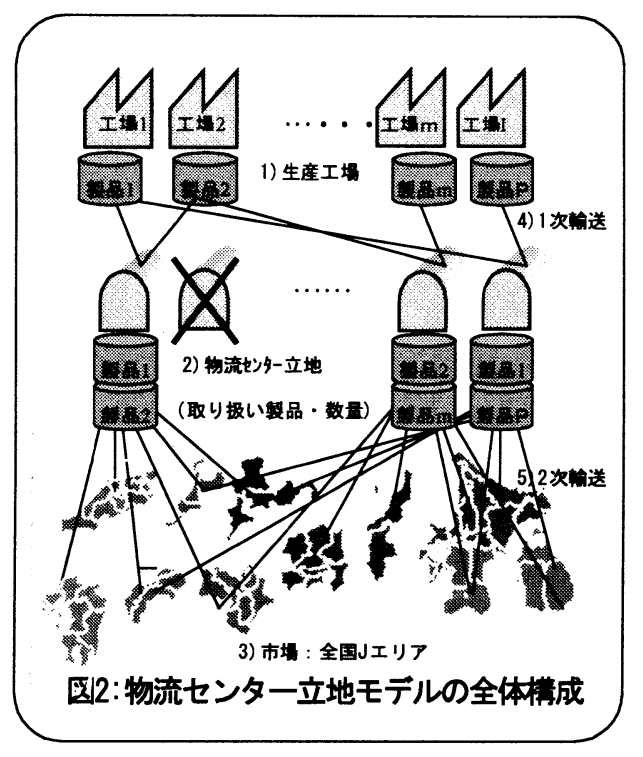
ンハント、20世紀初期のウェーバーらにより工場立地問題 として展開される。以来、最適配置問題は大別して2つの流 れとなり現在に至り、研究が進められている。第 1 の流れは、 経済学的観点から最適配置問題を考えるものであり、その特 徵として平面上(連続的空間)での施設の全体的な均衡配置 と最適配置の関連に焦点が当てられている。モデルとしては、 トン・キロ (輸送量 $\times$ 輸送距離) が最小となる施設配置を求 める重力モデル、市場までの最大距離の最小化モデル等々が 上げられる。第 2 の流れは、OR 分野での立地最適化であり、 ネットワーク上(離散的空間)での部分的な最適配置に焦点 を当てている。これは施設候補地、市場をノードとして、そ れらのリンクを輸送経路としてとらえ、そのネットワークの もつエネルギーを最小にすることにより最適配置を求める モデル等々である。

本研究の初期段階において、本命題が明らかに多段階最 適立地として取り扱うべき問題であり、製品の移動だけでな く中間チャネルでの製品の取り扱いをも考慮すべき問題で ある等の理由により、同質的な命題を取り扱う MMFLA モ デルをマイルストーンとして位置付けることが適当である という結論に達した。この MMFLA モデルは前述の第 2 の 流れを継承しつつも第 1 の流れ同様、平面上の最適配置を求 めるものと考えられる。

\section{（1）モデル㩰築の方向性}

同質的命題を取扱い、既存の立地選定モデルの中では本 命題に対し比較的適用性が高いと判断される MMFLA モデ ルの本命題への適用性を検討することにより、物流センター 立地モデル構築における方向性を策定する。

MMFLA モデルとは、Multiechelon Multiactivity Facility Location Allocation モデルの頭文字をとった略である。これ は、ペンシルバニア大学 (当時)の Mahmoud,Mohamed
Moustafaにより 1984 年に提案された費用最小化を目的とす る工場立地問題である。このモデルでは、2つの配送段階(入 カソース $\rightarrow$ 工場 に工場立地、生産ラインから市場まで輸送する製品数及び入 カソースから工場まで輸送する入力製品数を決定する。 MMFLA モデルは、(1)で示すような目的関数として定式化 され、分岐限定法 (上限值 : Greedy Drop 法、下限值 : ラグラン ジュ緩和法)により解かれている。

$$
\begin{aligned}
& \sum \mathrm{FiY}_{\mathrm{i}}+\sum \sum \mathrm{W}_{\mathrm{ipR}} \mathrm{Rip}+\sum \sum \sum \mathrm{C}_{\mathrm{ijp}} \mathrm{Xijp}_{\mathrm{ijp}} \\
& i \in I \quad \quad \quad i \in I p \in P \quad i \in I j \in J p \in P \\
& \text { (工場立地固定費) }+ \text { (生産ライン固定費) }+ \text { (製品輸送費) } \\
& +\sum \sum \sum \text { alimylim }+\sum \sum \mathrm{g}_{\mathrm{ip}}\left(\sum \mathrm{X} \mathrm{ijp}\right) \\
& l \in L i \in I m \in M \quad\{i \in I p \in P \quad j \in J \\
& \text { + (入力翰送費 }) \quad+(\text { 生産変動費 }) \\
& \text { - 工場立地数 } \quad \mathrm{i} \in \mathrm{I}=\{1, \cdots, \mathrm{I}\} \\
& \text { - 市場立地数 } \quad \mathrm{j} \in \mathrm{J}=\{1, \cdots, \mathrm{J}\} \\
& \text { - 入カソース立地数 } \quad \mathrm{l} \in \mathrm{L}=\{1, \cdots, \mathrm{L}\} \\
& \text { - 製品数 } \quad \mathrm{p} \in \mathrm{P}=\left\{1, \cdots, \mathrm{P}^{\prime}\right\} \\
& \text { - 入力品数 } \quad m \in M=\left\{1, \cdots, M^{\prime}\right\}
\end{aligned}
$$

\begin{tabular}{|c|c|}
\hline \multicolumn{2}{|c|}{ 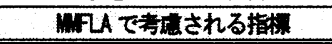 } \\
\hline \multirow{2}{*}{ 入カソース } & 材料種類 \\
\hline & ソース別物量 \\
\hline \multirow{3}{*}{ 生産拠点 } & 設備固定費 \\
\hline & 生産ライン固定費 \\
\hline & 生産変動費 \\
\hline 市場 & 市場別需要量 \\
\hline \multicolumn{2}{|c|}{ 入・出力輸送費 } \\
\hline
\end{tabular}

MMFLA モデルの本命題への適用を検討した結果、以下 に示す問題点が発生した。

\begin{tabular}{|c|c|}
\hline \multicolumn{2}{|c|}{ 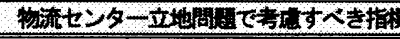 } \\
\hline \multirow{3}{*}{ 生産拠点 } & 工場別製品種類 \\
\hline & 工場別製品数量 \\
\hline & 製品別重量(または単位) \\
\hline \multirow{4}{*}{$\begin{array}{l}\text { 物流セン } \\
\text { ター }\end{array}$} & 地域別在庫スペース費用 \\
\hline & 地域別人件費 \\
\hline & 地域別発注管理費 \\
\hline & 製品別必要在庫スペース \\
\hline 市場 & 市場別需要量 \\
\hline & 入 \\
\hline
\end{tabular}

・設定条件の相違及び複雑化に伴うアルゴリズムの変 更・拡張の必要性

- 計算量の増大に対する最適化技法の導入の必要性

MMFLA モデルで使用される指標・変数の数に比して本 命題の解法に必要なそれらが多い点(表 1,2)、設定条件の相 違及び複雑化等の点から条件設定の変更、アルブリズムの大 幅な拡張が必要である。また MMFLA モデルは使用される 各変数の数が増加すれば、指数関数的に計算量が増加するい わゆる NP 完全問題であり、かつアルゴリズムは大変複雑で あるため、適用範囲が表 3 に示すように制限があるとされて おり、現実問題への応用が極く狭い領域に限定されている。

上記問題点を本命題の解決における方向性・課題と位置 付け、モデルを構筑する。アルゴリズムの拡張、最適化技法 の導入については各々次項及び次章にて詳細を組める。

\section{表1:MFLAモデルにおいて}

考虑される条件
衣 2 : 本命㩆において 考后すべき条件 
表 3:MFLA モデルの適用簿囲

\begin{tabular}{|l|c|}
\hline \multicolumn{1}{|c|}{ 項目 } & 適用範井 \\
\hline 入力ソース数 & 5 \\
\hline 入力数 & 4 \\
\hline 工場立地数 & 6 \\
\hline 製品数 & 4 \\
\hline \hline 市場立地数 & 5 \\
\hline
\end{tabular}

\section{（2）モデル棈築の前提}

物流センター立地モデルの前提として以下の事項を定め た。

1）立地される物流センター数は、与えられた物流セ ンター数の範囲で決定する。

2）配送段階は生産工場凡物流センター↔市場の2段

階配送方式をとる。

3）製品品目は複数品目とする。

\section{（3）モデルの条件}

1) 生産工場 :

- 1工場で複数製品を生産する。但し、本研究における 命題では1工場1製品。

- 工場別・製品別の最大供給量を設定する。

2) 物流センター :

- 各候補地毎に人件費及び地代家賃を設定する。

・製品を扱わない物流センターは立地しない。

3）市場 :

・ 各市場毎に各製品の需要を設定する。

4) 翰送 :

- 各配送段階において各製品の輸送単位、単価を設定す る。

\section{（4）最適立地探索の基本的アルゴリズム}

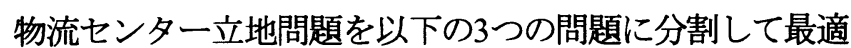
解を求める。これらは、立地総コスト最小となる物流セン ター立地、取り扱い製品品目及び数量の組み合わせを求め るものである。

[a 物流センター立地］物流センター立地並びに取り扱い 製品の最適集合を決定する。

[b 出カフロ一] [a]により得られた集合を用いて、物流セ ンターから市場まで輸送される製品品目・数量を決定する。

[c 入カフロー］[a]により得られた集合を用いて、生産工 場から物流センター一供給する製品品目・数量を決定する。

[a]は各物流センターの運営費に基づき、物流センター $\mathrm{i}$ $\left(\mathrm{i} \in \mathrm{I}=\left(1, \cdots, \mathrm{I}^{\prime}\right), \mathrm{I}:\right.$ センター立地数)を立地する決定係数、物流 センター $\mathrm{i}$ で製品 $\mathrm{p}(\mathrm{p} \in \mathrm{P}=(1, \cdots, \mathrm{P}), \mathrm{P}:$ 製品数 $)$ を取り扱う決 定係数を求める。

[b] [c]では[a]にて決定された集合を基にした割り当て問 題として、 $[\mathrm{b}][\mathrm{c}]$ 各々について輸送費最小となる割り当てを Greedy Method (貪欲法)により求める。

本研究では、[a]について次章以下で述べる遺伝的アルゴ リズム(Genetic Algorithm 以下 GA)を適用した。

\section{GAによる解法}

本モデルを命題で示される設定変数(生産工場数 : 6、物 流センター数：6、取り扱い商品数：6、市場数 : 6) で稼動さ せた場合、総当りによる最適解算出に必要な組み合わせ数は 約 690 億通りに及ぶ。 1 組に要する計算時間が約 0.0001 秒で あるため全組み合わせに要する計算所要時間は約 2.8 ケを 要する。これらの問題から、本モデルの計算効率の向上を目 的として、組み合わせ最適化問題に対して大域的な探索能力 を持つ遺伝的アルゴリズムを適用する。

\section{(1) GA の適用}

最適立地探索の基本的アルゴリズムにおいて物流センタ 一立地問題を $[\mathrm{a}$ 物流センター立地]、[b 出カフロー $] 、[\mathrm{c}$ 入力フロー］に分割した。これらに対し、GAにより[a]を扱 いそこで得られた集合をもとに各フロー問題([b][c])を多 目的ナップザック問題とみたて、Greedy Methodにより解き、 得られた割り当てによるコスト $(1,2$ 次輸送コスト) と、 [a] の集合により発生する物流センター運営費を GA の適応度 に組み込み、物流センター立地選定モデル全体として最適解 を求めた(図 3)。

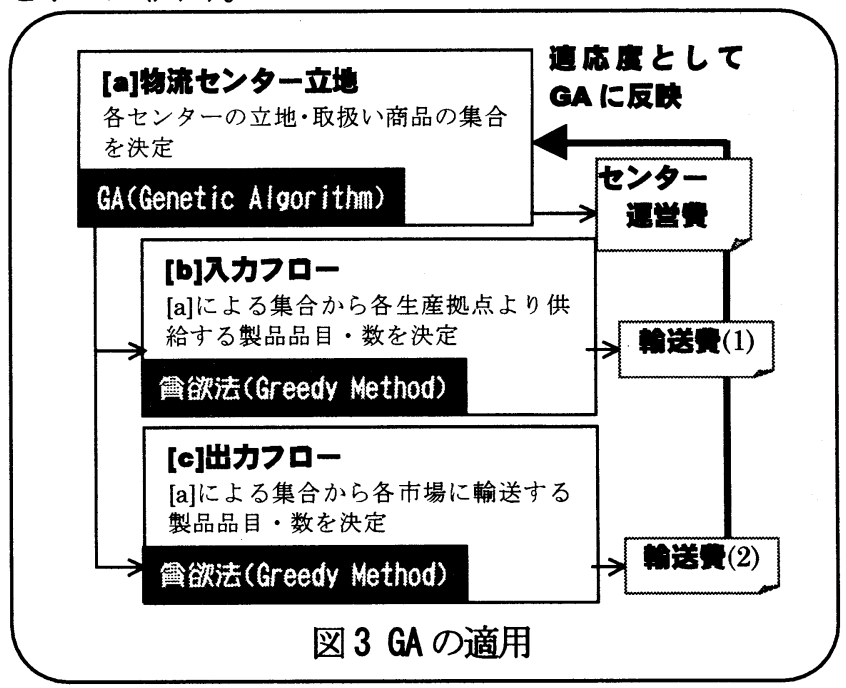

(2) GA によるコーディング

図 4 に本モデルにおける GA のコーディング方法を示す。

\section{（3）物流センター立地の遺伝子表現}

各ブロックは各物流センターがどの製品を扱っているか を示している。各ブロック毎に左から製品 1 、製品 $2 、 \cdots \cdots$. 製品 6 を表しており、遺伝子が 0 の場合はその物流センター では対象となる製品を取り扱わない。図 5 において、センタ -1 では製品 3 のみを取り扱い、同様にセンター2 では製品 2,4を取り扱う。また、センター5 は取り扱い製品がないた め立地されない。 


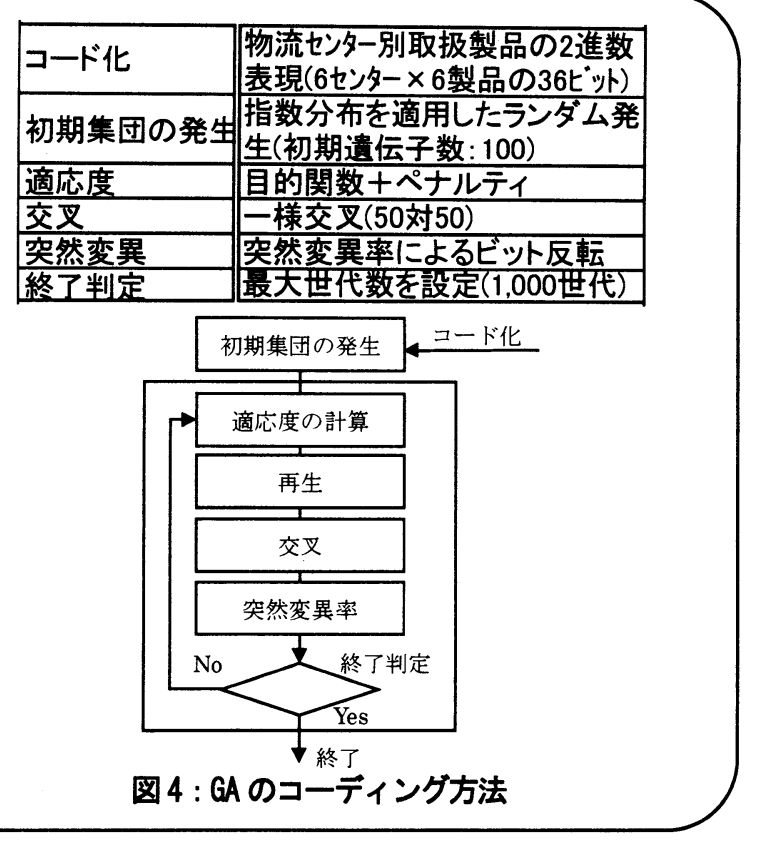

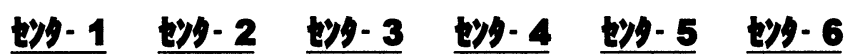

$\begin{array}{llllll}001000 & 010100 & 101000 & 001000 & 000000 & 001001\end{array}$

001000010100101000001000000000001001

図 5 : 遗伝子表現

\section{（4）フロ一割り当て}

各フロー問題にはGreedy Methodを採用し、[a]物流センタ 一立地問題により与えられた物流センター立地並びに取り 扱い製品の集合に対して製品数または入力品数の割当てを 決定する。[b]出力フロー(式(2))では、製品別にすべての市 場の需要量を、立地される物流センターに対しその保有在庫 数内で割り当てる。その際、製品輸送費を考慮し、より小さ いものから局所的に割り当てる。[c]入力フロー(式(3))につ いても [b]と同様に入力輸送費を考虑して各生産会社の最大 供給数量内に入力品数を割り当てる。

$\Sigma \Sigma \Sigma \mathrm{c}_{\mathrm{ijp}} \mathrm{X}_{\mathrm{ijp}}$

$i \in I j \in J p \in P$

$\Sigma \Sigma \Sigma$ alipylip

$l \in L i \in I p \in P$

・センター立地数 $i \in I=\{1, \cdots, I\}$

- 市場立地数 $\quad \mathrm{j} \in \mathrm{J}=\{1, \cdots, \mathrm{J}\}$

- 工場立地数 $\quad 1 \in \mathrm{L}=\left\{1, \cdots, \mathrm{L}^{\prime}\right\}$

- 製品数 $\quad \mathrm{p} \in \mathrm{P}=\left\{1, \cdots, \mathrm{P}^{\prime}\right\}$

cijp :センターiから市蚫jへの製品pの輸送費

Xijp :センターiから市場jまで配送される製品pの量

alip :工場1からセンターiへの製品pの輸送費

Ylip :エ場ソース1からセンターiまで輸送される製品pの量

例として[b]におけるアプローチを以下に示す。

[Step. 1]製品毎に割り当てを行う。

[Step. 2]各市場に対して製品需要の多い順にランク付けする。

[Step. 3]ランキング1位の市場からの輸送費が最も小さい物流セン
ター(立地される)に、保有存庫数内で割り当てる。

[Step. 4] [Step. 3] で割り当てた分の製品需要量を、その市場の需

要量及ひ物流センターの保有在庫数から減算する。

[Step. 5]再びランク付けを行う。

[Step. 6]ランキング1位の市場の需要量が0になるまで [Step. 3]に 戻る。

[Step. 7]すべての製品の割り当てが終了するまで [Step. 1]に启る。

\section{5. 多段階物流センターの最適配置の探索}

多段階物流センターの最適配置探索を行うために用いた計 算機環境は表 4 に示す通りである。

表 4 : 計算機摆境

\begin{tabular}{|c||c|}
\hline \hline 使用機種 & DEC ALPHA STATION 500 \\
\hline 使用 OS & Digital UNIX V4.0A \\
\hline 使用言語 & C 言語 \\
\hline \hline
\end{tabular}

\section{（1）使用データ}

表 5 に示す条件をモデルサイズとして物流センター立地 選定及ひ製品取り扱い形態の最適解を算出する。なお、市場 エリア数については、(1)各物流センタ一担当エリア再眍分の 必要性、(2)2 次輸送に宅配便を使用の 2 点から現状值とは異 なる 12 エリアとした。GA 操作における適応度として使用 する費目及び算出に用いたデータを表 6 に示す。

表 5 : モデルサイス

\begin{tabular}{|l|c|l|}
\hline \multicolumn{1}{|c|}{ 項 目 } & 数值 & \multicolumn{1}{c|}{ 借 考 } \\
\hline \hline 生産工場数 & 6 & 現状数値 \\
\hline 製品数 & 6 & 現状数值 (1 工場 1 製品) \\
\hline 物流也タ一候補地数 & 6 & 現状数值 \\
\hline 市場エリア数 & 12 & $\begin{array}{c}\text { 宅配便料金区分による } \\
\text { (現状値 : 6) }\end{array}$ \\
\hline
\end{tabular}

表 $6:$ 费用算出データ

\begin{tabular}{|c|c|}
\hline 算出貫目 & 使用データ \\
\hline 1 次輸送費 & $\begin{array}{l}\text { 各工場・各物流也歼間の宅配便運賃(宅配 } \\
\text { 便最大单位 } 25 \mathrm{~kg} \text { 以下に設定) }\end{array}$ \\
\hline 2 次輸送費 & 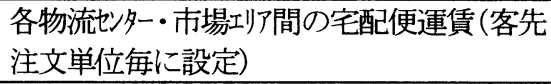 \\
\hline 物流セ多一運営費 & 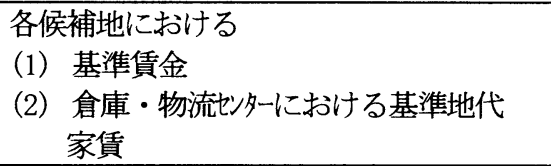 \\
\hline
\end{tabular}

\section{（2）シミュレーション結果}

本命題における解となる(1)総费用(輸送費十センター運営 費)による選定に加え、モデルの妥当性検証の観点から(2軨 送費用及び(3センタ一远営費の 3 面から物流センターの最 適立地を選定し、現状とのコスト比較を図 6, 表 7 に示した。 また、選定された物流センター立地、取り扱い製品及び担当 エリアを表 8,9,10 に示す。

尚、選定方法は各々の費用を $\mathrm{GA}$ の適応度に取り入れるこ とにより実現した。すなわち、(1)総費用による選定では輸送 
費及びセンター運営費を適応度に反映させ、(2)輸送費用、(3) 通営費による選定では各々輸送費、運営費のみを適応度に反 映させた。

\section{（a）費用面からの考察}

輸送費および総費用からの選定を行った結果、現状に比 ベ8〜11\%程度コストが削減されている(表 7)。特に(1)総費 用から選定では約 1,500 万円の削減結果を得ている。(2)輸 送費から選定での輸送費削减は、現状での輸送·在庫形態(総 ての製品を各工場から輸送し、総ての物流センターで保有） と、表 9 から判断されるように工場仓物流センター間の 1 次輸送距離が大幅に減少され、輸送費用が安価になったもの と思われる。（3通営費から選定では拠点集約により、現状に 比して運営費は激减しているものの輸送費が約 40\%の増加 を示している。また、(1)総費用から選定では、拠点集約効果 によりセンター運営費が約 22\%削減されている。

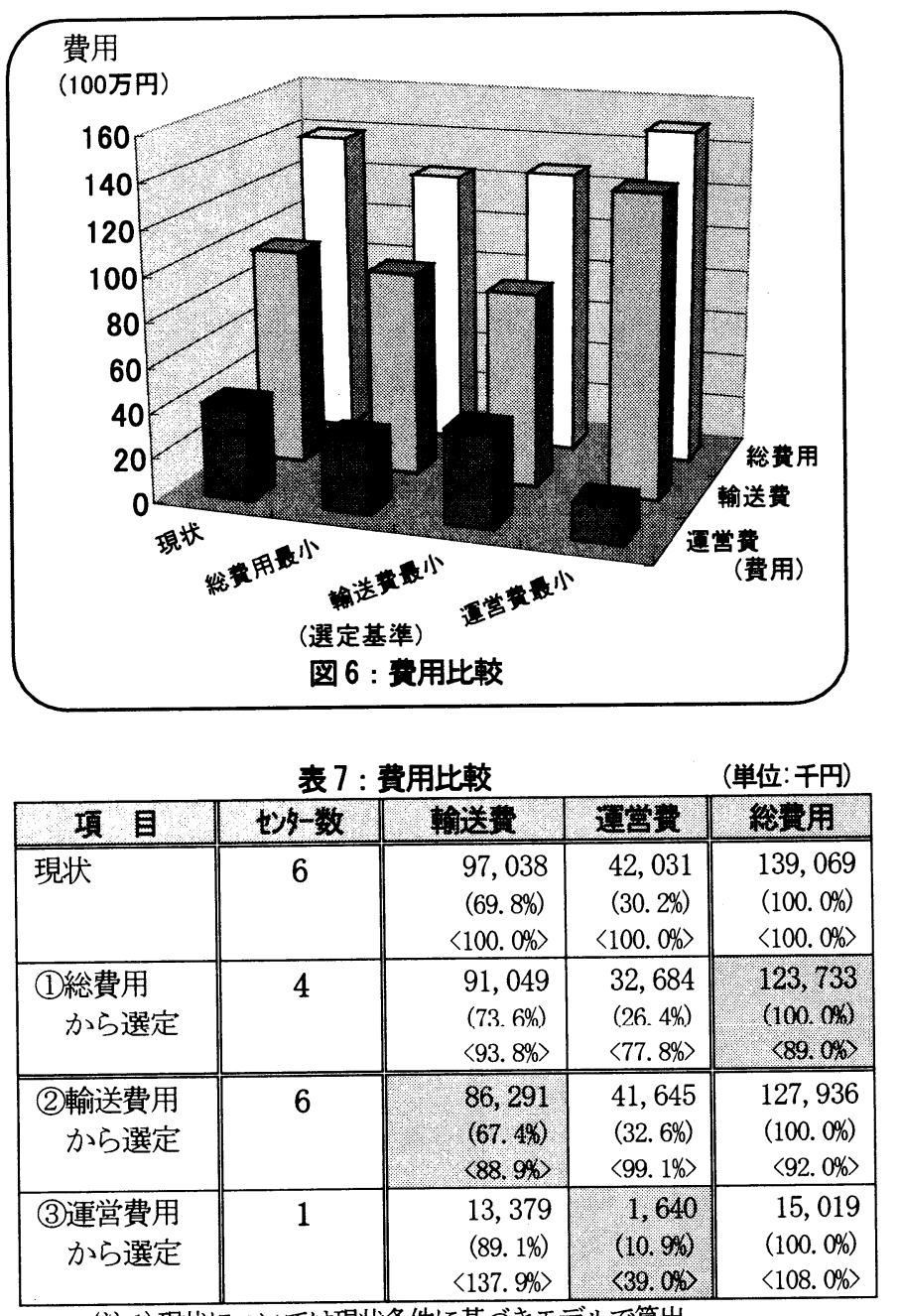

(注 1)現状については現状条件に基づきモデルで算出

(注 2) 表内() は総費用に占める割合、〈〉は現状との比率を示す

\section{(b) 拠点集約面からの考察}

(1)総費用から選定において、入間市(埼玉)、豊田市(愛知)、 守口市(大阪)、鹿本郡(熊本)に所在する物流センターが選定 されここの時物流センター数は 6 から 4 几集約されている。 これは当初推定された、「人件費、地代家賃が安価な地域へ の集約」とは反する結果となったが、全国規模の輸送拠点と して常に有力視される「東京、愛知、大阪、福岡」に準拠し
ている点、総費用の約 7 割を輸送費が占める点から妥当な結 果と言える。

(3運営費から選定では最適解探索に輸送費が考慮されな いため、単純に「人件費、地代家賃が安価な地域」である鹿 本郡(熊本)に集約された。

\section{(c) 輸送 · 在庫形態からの考察}

「総ての製品を、総ての物流センターで保有し、近距離エ リアの市場に向けて発送する」現状の輸送・在庫形態が、物 流センター↔市場間の 2 次輸送を重視したものである。これ に対して(2输送費から選定においては、物流センター周辺の 工場からの製品のみを在庫として持ち、全エリアに発送を行 う、工場 $\Leftrightarrow$ 物流センター間の 1 次輸送を重視したものとなっ た。

また、(1総費用から選定による結果は、各物流センター 周辺の工場で生産される製品は各々物流センターのみ保有 し、廃止されたセンター周辺工場の製品は他のセンターが保 有し、近距離エリアへ各々発送する。いわば、現状と(2)輸送 費から選定の中間的位置付けに存在する。

(3)通営費から選定では集約された 1 拠点で総ての製品を、 保有し、全てのエリアの市場に向けて発送を行っている。

表 8 : 最適立地選定結果 (1)秷費用から選定

\begin{tabular}{|c|c|c|}
\hline 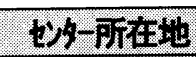 & 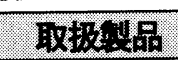 & 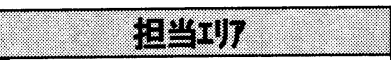 \\
\hline \multicolumn{3}{|l|}{ 仙台市(宮城) } \\
\hline \multirow[t]{2}{*}{ 入間市(埼玉) } & 製品 1 (宮城) & $\begin{array}{l}\text { 北東北、南東北、北海道、関 } \\
\text { 東、信州 }\end{array}$ \\
\hline & 製品 2(埼玉) & 全エリア \\
\hline \multirow[t]{3}{*}{ 豊田市(愛知) } & 製品 1(埼玉) & 中部、北陸、近畿 \\
\hline & 製品 3(愛知) & 全エリア \\
\hline & 製品 5(広島) & $\begin{array}{l}\text { 北東北、南東北、北海道、関 } \\
\text { 東、信州、中部、北陸、近畿 }\end{array}$ \\
\hline 守口市(大阪) & 製品 4(大阪) & 全エリア \\
\hline \multicolumn{3}{|l|}{ 佳伯郡(広禹) } \\
\hline \multirow[t]{3}{*}{ 鹿本郡(熊本) } & 製品 1 (宮城) & 中国、四国、九州、沖縄 \\
\hline & 製品 5(広島) & 中国、四国、九州、沖縄 \\
\hline & 製品 6(熊本) & 全エリア \\
\hline
\end{tabular}

(注) 取扱製品内 ()は工場所在県を示す

表 9 : 最端立地選定結果〜2輸送費用から選定

\begin{tabular}{|c|c|c|}
\hline 七タ-所在地 & 取扱制品 & 担当제) \\
\hline 仙台市(宮城) & 製品 1 (宮城) & 全エリア \\
\hline 入間市(埼玉) & 製品 2(埼玉) & 全エリア \\
\hline 豊田市(愛知) & 製品 3(愛知) & 全エリア \\
\hline 守口市(大阪) & 製品 4(大阪) & 全エリア \\
\hline 佐伯郡(広島) & 製品 5(広島) & 全エリア \\
\hline 鹿本郡(熊本) & 製品 6(熊本) & 全エリア \\
\hline
\end{tabular}

(注) 取扱製品内 () は工場所在県を示す

表 10 : 最商立地選定結果〜3センタ一远営費用から選定

\begin{tabular}{|c|c|c|}
\hline せター-所在地 & 取报留品 & 担当杪7 \\
\hline 价台市(宮城) & & \\
\hline 入率市 (埼至) & 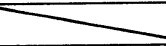 & \\
\hline 豊田市 (授知) & & \\
\hline 守口市(大阪) & & \\
\hline 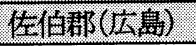 & & \\
\hline 鹿本郡(熊本) & 全製品 & 全エリア \\
\hline
\end{tabular}




\section{(d) 探索面からの考察}

本モデルでは計算効率の向上を目的として、組み合わせ最 適化問題に対して大域的な探索能力を持つ遺伝的アルゴリ ズムを適用した。その際の収束過程を図 7 に示す。これは、 淘汰率を $\{0.1,0.2,0.3,0.4\}$ 、突然変異率を $\{0.01,0.03,0.06\}$ 乙変 化させ、各々 10 回、計 120 回の探索を行った結果に対し分 散分析を施し、信頼率 $95 \%$ で啇応度に対する最適条件とし て有意であると判定される淘汰率 0.3 、突然変異率 0.03 の組 み合わせにより探索した際の収束を示したものである。また、 (a) (c)の各考察において、本モデルにおける解となる(1)総 費用から選定により示される選定結果がトレードオフの関 係にある(2)特送費、(3)通営费から選定による結果の中間的意 味合いを持つ点からほぼ妥当な探索が行われ、近似的最適解 が得られているといえる。

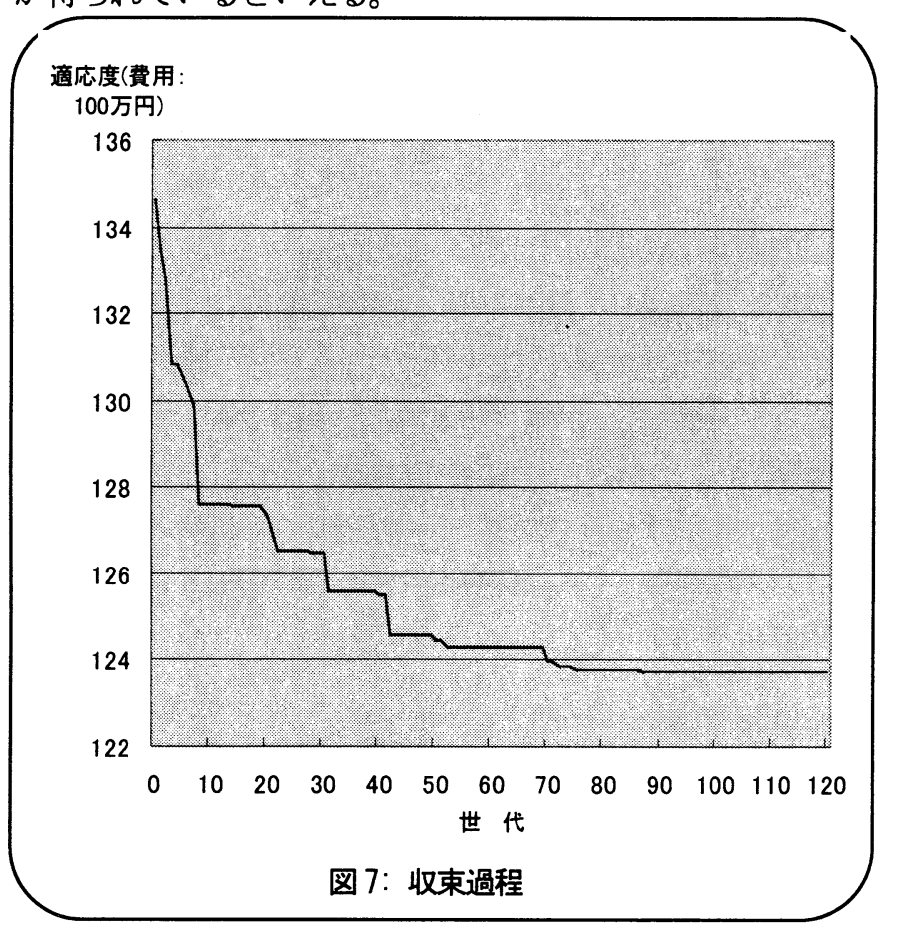

最適立地選定までの探索時間は約 20 秒前後と総当たりに よる処理時間(推測 2.8 ケ月)に比較して大幅な削減が達成さ れる共に、モデルサイズの確認として実験を行った結果、生
産工場数 : 12 、物流センター数 : 12 、取り扱い商品数: 12 、 市場数 : 12 までの適用が確認された。

\section{6. おわりに}

本研究では、社会的物流インフラ配置問題の解決の第 1 歩として、現実問題として提示された命題について最適解の 算出・検討を行うと共に、輸送費、センター運営費両者を考 慮した多段階立地選定モデルを開発した。また、最適化技法 として GA を適応することにより大幅な探索時間の削減を 達成し、今後のモデルサイズ抬張への足掛かりを確立した。

さらに近い将来、本モデルをべースとして広域エリアに おける供給地、セントラル・ハブ、ローカル・ハブ等の社会 的ハブの最適化問題へと発展させ、社会的インフラとしての 最適ハブシステムのさらなる研究に着手すると共に、それら の研究成果により、本モデルの一般化に伴う留意点や制約に ついても検討を進める予定である。

\section{参考文献}

1) Mahmoud,Mofhamed Moustafa: "An Efficient Algorithm For The Multiechelon Multiactivity Facility Location-Allocation Problem under Economies of Scale ", The Thesis for PH.D, University of Pennsylvania, 1984

2) 唐澤豊:"物流システム入門",株式会社現代工学社発行,1976年1月 20 日初版

3）角田直登,内田 智史,唐澤 豊:"GA による MMFLA モデルの解 法",日本経営工学会平成 8 年度秋期大会予稿集,pp.260-261

4）相浦宣徳、唐澤豊、佐藤馨一："GAによる MMFLA モデルの解 法"、日本物流学会誌, 1998,p.p.91-100

5）岡部篤行,鈴木敦夫:"最適配置の数理”,株式会社朝倉書店発 行,1992 年 4 月 20 日初版

6）佐々木修,工藤紀彦,谷津進,直井知与,"実践実験計画法”,日本工業 新聞社発行, 1985 年 11 月 30 日初版

7) 高橋洋二, 高田邦道, 㞳美宗, 苦瀨博仁, 岩尾詠一郎, 嶋野崇文, 根本敏則, 片山真登, 百合本莸,"都市物流シハステ改善の新たな取組み゙”, 土木 計画学研究·講演集NNo. 21(1) スペシや比ッション, 1998年11月, pp627-634

GA を用いた多段階物流センター最適立地選定に関する研究*

相浦 宣徳*佐藤 馨一***唐澤 豊

本論文はハード面からの社会的物流インフラ配置問題解決の第 1 歩として、ある企業において現実に提示されている物流 センター立地問題の解決、並びに多段階物流センター最適立地問題の解法の確立を目的としたものである。すなわち、輸送 コストをベースとした多段階物流センター立地選定モデルの開発を行い、さらに製品在庫の持ち方、各物流センター拠点候 補地における人件費、地代家賃等から発送管理費、在庫維持費等のセンター運営費を考慮した多段階立地選定モデルへの発 展を図った。今後、本モデルをベースとして広域エリアにおける供給地、セントラル・ハブ、ローカル・ハブ等の社会的八 ブの最適化問題へと発展させ、社会的インフラとしての最適ハブシステムの研究に取組む予定である。

\section{Research for Optimal Location of Multiechelon Distribution Center Based on Genetic Algorithm}

Nobunori AIURA, Keiichi SATOH,Yutaka KARASAWA and Naoto TSUNODA

This paper aims at solving optimization problems for locating distribution centers as a first step of investigation of social distribution problems, which are actually presented in some company. We construct a multiechelon model based on transportation costs for selecting its location optimally by considering goods in stock, labor costs spent at the centers, rent on the centers and charge for management. In future, we try to develop this model to a more general one suited to optimization problems of social hub such as central hub and local hub in a broad area and investigate a construction of optimal hub system as a social infra. 